\title{
BMJ Global Health Is living in a gas-flaring host community associated with being hypertensive? Evidence from the Niger Delta region of Nigeria
}

\author{
Omosivie Maduka, Charles Tobin-West
}

To cite: Maduka 0 , Tobin-West C. Is living in a gas-flaring host community associated with being hypertensive? Evidence from the Niger Delta region of Nigeria. BMJ Glob Health 2017;2:e00413. doi:10.1136/ bmjgh-2017-000413

Handling editor Seye Abimbola

Received 18 May 2017

Revised 3 September 2017 Accepted 6 September 2017
CrossMark

Department of Preventive and Social Medicine, College of Health Sciences, University of Port Harcourt, Port Harcourt, Nigeria

Correspondence to Dr Omosivie Maduka; omosivie.maduka@uniport. edu.ng

\section{ABSTRACT}

Background Researchers have linked gas flaring to climate change, the hastening of the epidemiological transition and an upsurge in the prevalence of noncommunicable diseases. We sought to determine if a relationship exists between residing in a gas-flaring host community and hypertension.

Methods We conducted an analytical cross-sectional household survey among residents of 600 households in three gas-flaring and three non-gas-flaring host communities in the Niger Delta region of Nigeria. We took geo-coordinates, administered a modified WHO-STEPS questionnaire and built on Android mobile phones using Open-Data-Kit (ODK) software. We also took biological measurements and carried out descriptive and inferential statistical analysis using SPSS and STATA.

Results We interviewed a total of 912 adults: 437 (47.9\%) from non-gas-flaring and 475 (52.1\%) from gas-flaring host communities. There were differences in level of education ( $x 2=42.99 ; p=0.00)$, occupation category $(x 2=25.42 ; p=0.00)$ and BMI category $(x 2=15.37$; 0.003 ) among the two groups. The overall prevalence of hypertension was $23.7 \%$ : $20.7 \%$ among persons living in non-gas-flaring host communities compared with $25.3 \%$ among persons living in gas-flaring host communities $(x 2=2.89 ; p=0.89)$. Residence in a gas-flaring host community, (AdjOR=1.75; $95 \% \mathrm{Cl}=1.11$ to 2.74$)$ and mean age (AdjOR=1.05; $95 \% \mathrm{Cl}=1.03$ to 1.07 ) were identified as the predictors of hypertension. There was a significant association between hypertension and age, 1.05 (1.041.06) while the probability of being hypertensive was higher among residents of gas-flaring host communities between 20 to 40 years and 60 to 80 years.

Conclusion There is a need for the relevant agencies to scale up environmental and biological monitoring of air pollutants. The implication of a possible relationship between gas-flaring and hypertension brings to the fore the need for interventions to regulate gas-flaring activities.

\section{INTRODUCTION}

Nigeria is Africa's largest producer of crude oil and the sixth largest producer in the world, ${ }^{1-3}$ with a capacity to produce approximately 2.5 million barrels per day. ${ }^{4}$ The country has been producing crude oil since the 1950s when

\section{Key questions}

What is already known about this topic?

- Air pollution has been associated with an increase in the prevalence of hypertension and other non-communicable diseases.

- Communities in the Niger Delta which are host to gas-flaring activities are exposed to gas-flaringinduced air pollution.

- A previous study in the Niger Delta has linked oil pollution to increased prevalence of hypertension.

\section{What are the new findings?}

- Persons living in gas-flaring host communities are 1.75 times more likely to be hypertensive than persons resident in communities without oil exploration activities.

- The prevalence of hypertension in the study population was moderated by the age of study participants with those at both extremes of adult age residing in gas-flaring host communities being more hypertensive compared with similar persons in non-gas-flaring communities.

Recommendations for policy

- Study findings provide the impetus for stricter prevention and control measures for gas-flaring activities in the Niger Delta region of Nigeria.

- More attention need also be given to interventions for prevention and control of socio-economic lifestyle determinants of hypertension, especially among residents of oil- bearing communities.

deposits were first discovered in Oloibiri in what is now known as Bayelsa state. Oil and natural gas extraction currently account for up to $97 \%$ of the country's revenue from foreign exchange, $20 \%$ of the country's GDP and $65 \%$ of budgetary revenue. Nigeria is also blessed with huge deposits of natural gas located mainly in the Niger Delta region of the country. ${ }^{56}$ Despite this obvious wealth, Nigeria is ranked among the poorest countries in the world with over half of its population living on less than two dollars a day. ${ }^{6}$ 
Gas-flaring, which is routinely carried out by oil exploration companies in Nigeria, also poses a significant hazard to the health of populations exposed to it. It pollutes the air, heats up the atmosphere and releases greenhouse gases. ${ }^{78}$ Although Nigeria pledged to stop gas-flaring and has imposed fines on oil exploration companies still flaring gas in the country, the practice of gas-flaring has not stopped. ${ }^{9}$ Many of these companies admit that flaring of associated and non-associated gas is wrong and wasteful, but they also contend that the oil and gas sector in Nigeria faces infrastructure and technology obstacles in adequately harnessing natural gas. Consequently, Nigeria ranks as the 10th highest contributor to flaring of natural gas worldwide with flares of up to 426 billion cubic feet (bcf) of gas in 2013, representing $10 \%$ of gas-flaring worldwide. ${ }^{910}$ Many companies in the Niger Delta have only reduced flaring by a mere $10 \%$ since 2007 preferring to pay fines rather than to abate gas-flaring activities. ${ }^{8}$ The country had only succeeded in achieving a minimal reduction in gas-flaring from 540 bcf in 2010 to 428 bcf in 2013. ${ }^{10}$

The process of gas-flaring results in the dissemination of greenhouse gases (GHG) and other air pollutants such as carbon dioxide $\left(\mathrm{CO}_{2}\right)$, methane $\left(\mathrm{CH}_{4}\right)$, ethane, propane, butane, hydrogen sulphide $\left(\mathrm{H}_{2} \mathrm{~S}\right)$ and nitrous oxide $\left(\mathrm{NO}_{2}\right)$. Greenhouse gases have long been implicated in global warming and climate change. ${ }^{7}$ There is evidence of the adverse effects of heat-trapping gases on surface temperature. ${ }^{71}$ Apart from the effect on atmospheric temperature, the gases flared serve as pollutants to air and water. Greenhouse gases also precipitate the formation of acid rain. All this leads to negative outcomes in the health of the people who live and work in communities that are exposed to gas-flaring activities. These health outcomes range from chronic and recurrent respiratory diseases, abnormal haematological indices and increased susceptibility to blood dyscrasias, dermatological diseases and malignancies among others. The association between global warming and disease transmission has also been noted. ${ }^{78}$

Several researchers have hinted at the relationship between air pollution and non-communicable diseases such as hypertension. ${ }^{12-21}$ However, this has not been demonstrated in the Niger Delta region of the country except for a recent publication which showed an association between residing in an oil-polluted environment and the prevalence of hypertension. ${ }^{22}$

We determined the relationship between residence in a gas-flaring host community and the prevalence of hypertension in six Niger Delta communities in Nigeria. This research was part of a larger survey titled 'Epidemiological assessment of the health and well-being of residents of communities exposed to gas-flaring activities in the Niger Delta region of Nigeria' which explored morbidity and mortality patterns of persons living in gas-flaring host communities.

\section{MATERIALS AND METHODS}

The Niger Delta region of Nigeria as defined by the Nigerian government occupies about $70000 \mathrm{~km}^{2}$ and makes up $7.5 \%$ of Nigeria's land mass. It comprises the nine oil-producing states in the country namely: Bayelsa, Rivers, Delta, Akwa Ibom, Cross River, Edo, Abia, Imo and Ondo. These states are home to about 31 million people spanning more than 40 ethnic groups and 185 Local Government Areas (LGAs). The inhabitants speak about 250 different dialects This research was part of a larger study conducted to compare morbidity and mortality of persons residing in gas-flaring host communities with those residing in communities where there are no oil exploration activities, using an analytical cross-sectional household survey. Rivers, Bayelsa and Delta states arguably have the highest number of oil exploration and gas-flaring activities in the Niger Delta of Nigeria and so were purposively sampled for the study. We chose two communities from each of the three states: one 'exposed' community and one 'un-exposed' community.

A total of six communities, Sampou and Nedugo in Bayelsa state, Ibada-Elume and Oton-Yasere in Delta state, and Omerelu and Mbodo-Aluu in Rivers state were selected. Nedugo, Oton-Yasere and Mbodo-Aluu were designated as gas-flaring host communities (host to gas-flaring activities for a minimum of 10 years with gas-flaring activities occuring within a five-kilometre radius from community settlements). Sampou, IbadaElume and Omerelu were designated as non-gas-flaring communities (no history of exposure to any oil exploration activities and not contiguous with exposed communities). These communities were, however, in the same state as exposed communities with similar population size, structure and socio-demographic characteristics as gas-flaring host communities. Individuals included in the household survey were all current residents of the selected communities, who were born into that community or had lived there for a minimum of 10 years.

A minimum sample size of 964 adults (482 resident in gas-flaring host communities and 482 resident in non-gasflaring, and 880 not exposed) was considered adequate to determine a difference in prevalence of hypertension among the two groups of communities using the formula for difference between two proportions. This calculation was done using Winpepi version $9.7,{ }^{23}$ with power set at $80 \%(\mathrm{u}=0.84)$ and a $5 \%$ significance level $(\mathrm{v}=1.96)$. From a previous study, the proportion of study participants in the oil-polluted community in Rivers state who were hypertensive (p1) was $43.3 \%$, while the proportion of hypertensive persons in the non-polluted community (p2) was $31.2 \% .^{22}$ A $10 \%$ mark-up in sample size was done to allow for non-response and multiplication by a factor of two used to correct for design effect.

Based on an estimate of an average of two adults per household, a total of 600 households (100 households per community) were targeted for data collection. We visited each household once and studied all eligible and 
available adults in 600 households. We did not conduct repeat visits. The geographical zones/villages in each community were identified based on an oral history provided by community gatekeepers such that the total number of households per community was further divided into these zones/villages. The first households studied in each zone/village was selected by tossing a coin between the two households closest to the village/ zone centre. Subsequently, every household adjacent to the last sampled household was included if the residents met the eligibility criteria.

An interviewer-administered questionnaire adapted from the WHO STEPS questionnaire was used to obtain information on morbidity and mortality patterns in the study communities. It had the following sections: consent form, socio-demographic and household information, and physical measurements such as weight, height and blood pressure.

Every respondent had their blood pressure measured twice (at the start and end of the interview) using the Omron 3 Series Upper Arm Blood Pressure Monitor with wide-range cuff $(\mathrm{BP} 710 \mathrm{~N})$. Appropriate cuffs sizes were used at all times, and blood pressure was taken while the study participant was comfortably seated. The mean of the two readings (rounded off to the nearest whole number) was used. Hypertension was defined as systolic blood pressure $\geq 140 \mathrm{mmHg}$ and/or diastolic $\mathrm{BP} \geq 90 \mathrm{mmHg}$, or persons on anti-hypertensive medication irrespective of their observed blood pressure. Persons identified as hypertensive for the first time were referred to the nearest Primary Health Centre.

The weight of study participants was measured in kilograms using the Seca Clara 803 Digital Personal Scale. Study participants stood barefoot on the scale, and the weight was recorded by the research assistant based on readings from the scale. The Doran Scales Mechanical Height Rod Stadiometer was used to take all height measurements. Height was measured in metres and measurements taken barefoot with the study participants standing up straight against the vertical ruler.

The data collection tool was built and uploaded on Android mobile phones using the Open Data Kit software. A server domiciled in the WHO state office was set up for real-time upload and storage of completed questionnaires. Six Android mobile phones which are GPS-enabled were used for data collection including the

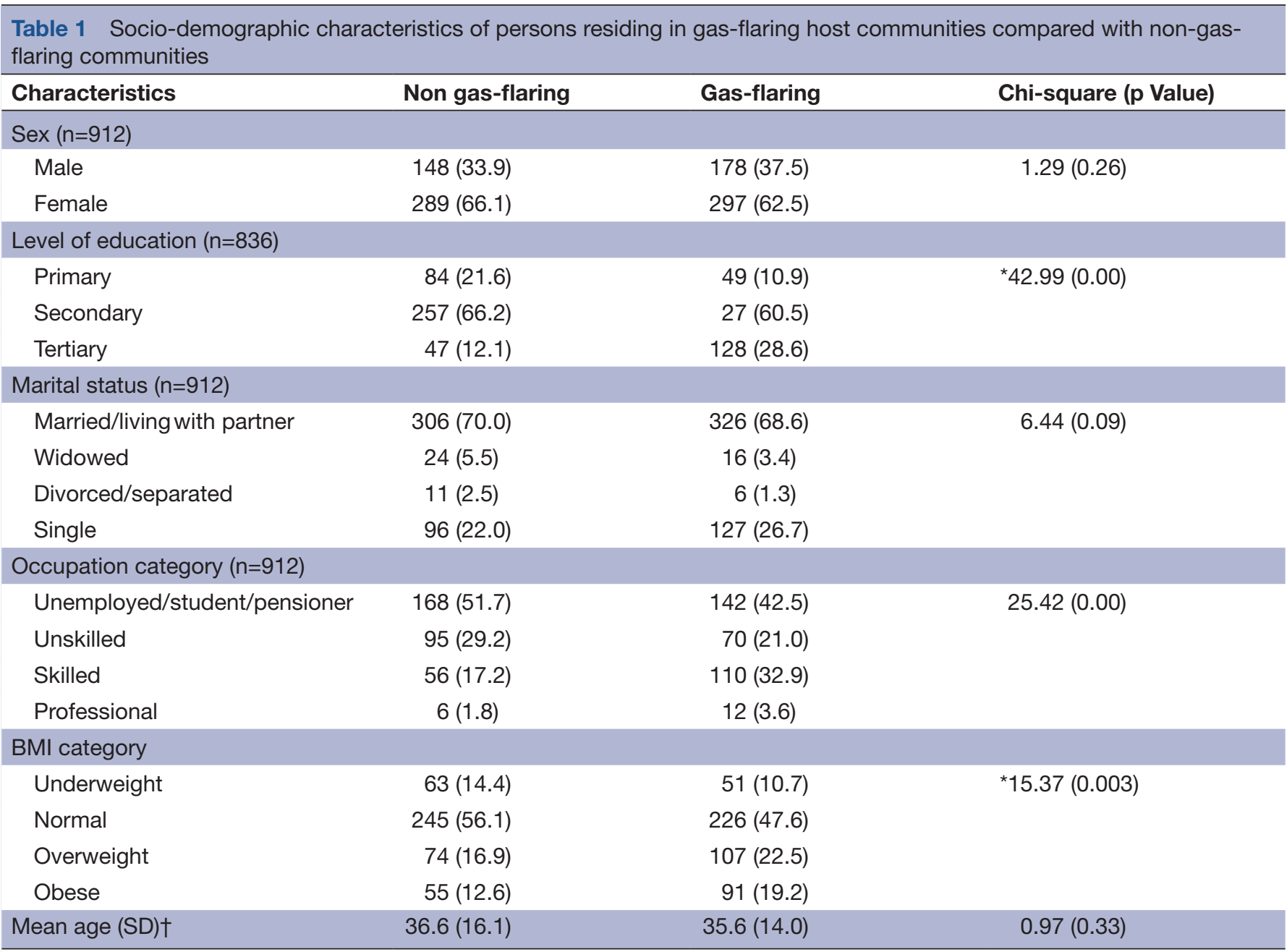

${ }^{*}$ significant Chi-square values at $p<0.05,+t$-test ( $p$-value). 
capture of the GPS coordinates for each household. We recruited and trained six field data collectors who were university graduates to administer the study tool. These data collectors were blinded to the objectives of the study and the purpose of the physical measurements as a means of controlling measurement bias. In each community, we further recruited another five persons who were indigenes to work with each data collector (making up a two-person team of one data collector and one indigene). The local recruits served as interpreters/guides/assistants to each data collector. Data collection was carried out over 14 working days in May 2016 with an average of 2 days spent in each community. Each data collection team collected data from a minimum of 20 households per day.

\section{DATA ANALYSIS}

Data was downloaded from the WHO server in Microsoft Excel 2013 version for data cleaning and analysed using Statistical Package for the Social Sciences (SPSS) version
21 and STATA version 14 with descriptive and inferential statistics carried out, Chi-square test, t-tests, analysis of variance, simple logistic and multiple logistic regression. We determined the fitness of the regression model using Hosmer-Lemeshow goodness-of-fit test regression diagnostics. We also performed the tolerance test for multicollinearity, link test to check for model specification error and plotted the receiver operating characteristic curves (c-statistics) analyses to determine the predictive powers of the final multivariate model. Results were presented as odds ratios (ORs) with 95\% confidence intervals (CIs). The significance tests were 2-tailed, and statistical significance was defined at the alpha level of 0.05 .

\section{ETHICAL CONSIDERATIONS}

Ethical approval for the research was obtained from the research ethics committee of the University of Port Harcourt. A consent form explaining the study objectives, procedures, benefits and risks was prepared for all potential study participants to review and give written informed consent

Table 2 Prevalence of hypertension by socio-demographic characteristics in the study population

\begin{tabular}{|c|c|c|c|}
\hline & \multicolumn{2}{|l|}{ Study category } & \multirow[b]{2}{*}{ Chi-square ( $p$ Value) } \\
\hline & Non gas-flaring $(n=93)$ & Gas-flaring $(n=123)$ & \\
\hline \multicolumn{4}{|l|}{ Hypertension status } \\
\hline Hypertensive & $93(20.7)$ & $123(25.3)$ & $2.89(0.89)$ \\
\hline \multicolumn{4}{|l|}{ Sex } \\
\hline Male & $39(26.4)$ & $45(25.6)$ & $0.03(0.87)$ \\
\hline Female & $54(18.8)$ & $18(26.4)$ & *4.82 (0.03) \\
\hline \multicolumn{4}{|l|}{ Level of education } \\
\hline Primary & $23(27.4)$ & $18(37.5)$ & $1.46(0.23)$ \\
\hline Secondary & 39 (15.2) & $56(20.7)$ & $2.69(0.10)$ \\
\hline Tertiary & $10(21.3)$ & $38(29.9)$ & $1.28(0.28)$ \\
\hline Non-response & $21(42.9)$ & $11(40.7)$ & $0.32(0.86)$ \\
\hline \multicolumn{4}{|l|}{ Occupation } \\
\hline Unemployed/student & $39(23.3)$ & $42(29.8)$ & $1.71(0.19)$ \\
\hline Unskilled & 15 (15.8) & $20(29.0)$ & *4.15 (0.04) \\
\hline Skilled & $12(21.8)$ & $22(19.3)$ & $0.11(0.7)$ \\
\hline Professional & $2(33.3)$ & $4(33.3)$ & $0.00(1.00)$ \\
\hline \multicolumn{4}{|l|}{ Age group } \\
\hline 18 to 34 years & $24(9.5)$ & $45(16.1)$ & ${ }^{\star} 5.14(0.02)$ \\
\hline 35 to 54 years & $38(30.9)$ & $46(33.8)$ & $0.25(0.62)$ \\
\hline 55 to 74 years & $23(50.0)$ & $27(57.4)$ & $0.52(0.47)$ \\
\hline 75 years and above & $8(57.1)$ & $5(55.6)$ & $0.006(0.94)$ \\
\hline \multicolumn{4}{|l|}{ Body mass index } \\
\hline Underweight & $13(20.6)$ & $5(9.8)$ & $1.49(0.12)$ \\
\hline Normal & 40 (16.3) & $46(20.5)$ & $1.38(0.24)$ \\
\hline Overweight & $21(28.8)$ & $34(31.8)$ & $0.19(0.67)$ \\
\hline Obese & 19 (34.5) & $38(42.2)$ & $0.84(0.36)$ \\
\hline
\end{tabular}

*significant Chi-square values at $p<0.05$. 
(by signature or thumb print). Permission to carry out the study was obtained from the local government headquarters of each community and the community gatekeepers. Study participants were assured of confidentiality. Data collection tools did not bear participants names. All records generated remained in the custody of the researchers and were kept in a secure location. Data entry files were passworded to further guarantee confidentiality. Study participants were also informed of their rights to withdraw consent at any time during the study without concern for negative consequences.

\section{RESULTS}

\section{Socio-demographic characteristics of study participants}

A total of 912 adults (aged 18 years and above) were interviewed during the household survey giving a response rate of $94.6 \%$. A total of $437(47.9 \%)$ of these were residents of communities not exposed to gas-flaring, while 475 $(52.1 \%)$ persons were residents of communities exposed to gas-flaring activities. There was no difference in the mean age (SD) of respondents in communities not exposed to gas-flaring (36.6; 16.1 years) compared with respondents residing in communities exposed to gas-flaring activities (35.6; 14.0 years). A comparison of the distribution of socio-demographic characteristics across study categories revealed differences in level of education $\left(\mathrm{x}^{2}=43.0 ; \mathrm{p}=0.00\right)$, occupation category $\left(\mathrm{x}^{2}=25.4 ; \mathrm{p}=0.00\right)$ and BMI category $\left(\mathrm{x}^{2}=15.4 ; 0.003\right)$ table 1 .

\section{Prevalence of hypertension}

A total of 216 persons among the adults in the study were found to be hypertensive, giving an overall prevalence of $23.7 \%$. A total of $93(43.06 \%)$ hypertensive persons were residents of communities not exposed to gas-flaring, while 123 (56.94\%) hypertensive persons were residents of communities exposed to gas-flaring activities. These correspond to a prevalence of hypertension among persons resident in non-gas-flaring communities of $20.7 \%$ compared with $25.3 \%$ prevalence of hypertension among persons living in communities exposed to gas-flaring. These two prevalences were however not significantly different 2.89 (0.89). A comparison of prevalence of hypertension across socio-demographic characteristics is shown in table 2 . Females $\left(\mathrm{x}^{2}=4.82 ; 0.03\right)$, unskilled workers $\left(\mathrm{x}^{2}=4.15 ; 0.04\right)$ and persons aged $18-34$ years $\left(x^{2}=5.14 ; 0.02\right)$, living in communities exposed to gas-flaring activities had a higher prevalence of hypertension than those residing in communities not exposed to gas-flaring activities table 2.

Table 3 Predictors of hypertension using regression models

\begin{tabular}{|c|c|c|c|c|}
\hline \multirow[b]{2}{*}{ Variable } & \multicolumn{2}{|l|}{ Unadjusted } & \multicolumn{2}{|l|}{ Adjusted } \\
\hline & OR $(95 \% \mathrm{Cl})$ & p Value & OR $(95 \% \mathrm{Cl})$ & p Value \\
\hline \multicolumn{5}{|l|}{ Study category } \\
\hline $\begin{array}{l}\text { Residence in a gas-flaring versus } \\
\text { non- gas-flaring host community }\end{array}$ & $1.31(0.96$ to 1.76$)$ & 0.090 & *1.75 (1.11 to 2.74$)$ & 0.02 \\
\hline Mean age & ${ }^{*} 1.05$ (1.04 to 1.06$)$ & 0.000 & ${ }^{*} 1.05$ (1.03 to 1.07$)$ & 0.00 \\
\hline \multicolumn{5}{|l|}{ Sex } \\
\hline Female versus male & 0.82 (0.60 to 1.12$)$ & 0.20 & 0.9 (0.57 to 1.42$)$ & 0.65 \\
\hline $\mathrm{BMI}$ & 1.01 (1.00 to 1.02$)$ & 0.00 & 1.01 (0.99 to 1.02$)$ & 0.11 \\
\hline \multicolumn{5}{|l|}{ Levels of education } \\
\hline Primary (reference) & Reference & & Reference & \\
\hline Junior secondary & 0.2 (0.09 to 0.44$)$ & 0.000 & 0.51 (0.18 to 1.39$)$ & 0.19 \\
\hline Senior secondary & $0.52(0.34$ to 0.80$)$ & 0.003 & $1.08(0.59$ to 1.99$)$ & 0.80 \\
\hline Tertiary & 0.81 (0.49 to 1.32$)$ & 0.399 & 1.33 (0.67 to 2.64$)$ & 0.42 \\
\hline \multicolumn{5}{|l|}{ Marital status } \\
\hline Single (Reference) & Reference & & Reference & \\
\hline Married/living with partner & *2.96 (1.92 to 4.55$)$ & 0.000 & 1.59 (0.88 to 2.89$)$ & 0.13 \\
\hline Widowed & *8.39 (4.03 to 17.47$)$ & 0.000 & 1.45 (028 to 7.58$)$ & 0.66 \\
\hline Divorced/separated & ${ }^{*} 5.87$ (2.07 to 16.66$)$ & 0.001 & 3.95 (0.97 to 16.12$)$ & 0.06 \\
\hline \multicolumn{5}{|l|}{ Occupation } \\
\hline Unemployed/student (reference) & Reference & & Reference & \\
\hline Unskilled & 0.75 (0.48 to 1.17$)$ & 0.203 & 0.73 (0.420 to 1.25$)$ & 0.25 \\
\hline Skilled & $0.73(0.46$ to 1.14$)$ & 0.165 & $0.68(0.40$ to 1.15$)$ & 0.15 \\
\hline Professional & 1.46 (0.53 to 4.02$)$ & 0.460 & 0.90 (0.28 to 2.92$)$ & 0.86 \\
\hline
\end{tabular}

${ }^{*}$ Confidence Intervals showing significant association between variables and hypertension status. 


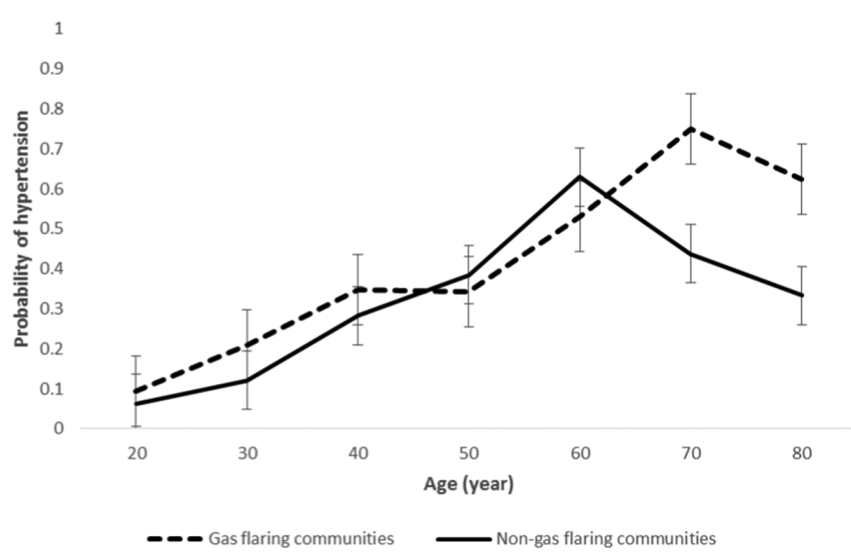

Figure 1 Predicted probability of hypertension for all ages by gas-flaring status.

\section{Association between hypertension and residence in gas- flaring host community}

We carried out bivariate and multivariate regression of the following independent variables found to be associated with hypertension status (dependent variable) at $\mathrm{p}<0.25$, gas-flaring status of the community of residence, age, sex, BMI, marital status, the level of education and category of occupation. Bivariate regression analysis showed that mean age $(\mathrm{OR}=1.05 ; 95 \% \mathrm{CI}=1.04$ to 1.06$)$, the status of being married/living with partner $(\mathrm{OR}=2.96 ; 95 \%$ $\mathrm{CI}=1.92$ to 4.55$)$, being divorced/separated $(\mathrm{OR}=8.39$, $95 \% \mathrm{CI}=4.03$ to 17.47$)$ and being widowed $(\mathrm{OR}=5.87$; $95 \% \mathrm{CI}=2.07$ to 16.66$)$ were related to being hypertensive. Table 3 However the multivariate regression model adjusted for confounders and identified residence in a community exposed to gas-flaring (AdjOR $=1.75 ; 95 \%$ $\mathrm{CI}=1.11$ to 2.74 ) and mean age (AdjOR $=1.05 ; 95 \%$

Table 4 Interaction of demographic variables and hypertensive status

\begin{tabular}{|c|c|c|}
\hline Interaction effect & $\begin{array}{l}\text { Odds ratio } \\
(95 \% \mathrm{Cl})\end{array}$ & p Values \\
\hline $\begin{array}{l}\text { Hypertensive (vs non- } \\
\text { hypertensive) x gas-flaring }\end{array}$ & $\begin{array}{l}1.30 \\
(0.96 \text { to } 1.76)\end{array}$ & 0.09 \\
\hline \multicolumn{3}{|l|}{ Model fit statistics } \\
\hline Area under ROC curve & & 0.53 \\
\hline Lemeshow test ( $p$ Value) & & 1.00 \\
\hline \multicolumn{3}{|l|}{ Link test ( $p$ Values) } \\
\hline $\begin{array}{l}\text { Collinearity diagnostic (mean } \\
\text { VIF) }\end{array}$ & & 1.00 \\
\hline $\begin{array}{l}\text { Hypertensive (vs non- } \\
\text { hypertensive) } x \text { age }\end{array}$ & $\begin{array}{l}1.05 \\
(1.04 \text { to } 1.06)\end{array}$ & $<0.001$ \\
\hline \multicolumn{3}{|l|}{ Model fit statistics } \\
\hline Area under ROC curve & & 0.74 \\
\hline Lemeshow test ( $p$ Value) & & 0.19 \\
\hline \multicolumn{3}{|l|}{ Link test ( $p$ Values) } \\
\hline $\begin{array}{l}\text { Collinearity diagnostic (mean } \\
\text { VIF) }\end{array}$ & & 1.00 \\
\hline
\end{tabular}

$\mathrm{CI}=1.03$ to 1.07$)$ as the only significant predictors of hypertension among the study participants table 3 .

Further analysis was done to determine the interaction effects and fit of the model between hypertension and gas-flaring status, and hypertension status and age. The interaction between hypertension status and age O.R 1.05 (1.04-1.06) was found to be significant, while that between hypertension and gas-flaring status was not O.R $1.30(0.96-1.76)$. This finding was supported by the area under the ROC curve which was 0.533 for hypertension versus gas-flaring status and 0.737 for hypertension versus age. Other model fit statistics are as shown in table 4 . The probability of being hypertensive was modified by age (figure 1) such that the probability of being hypertensive was higher among residents of gas-flaring host communities between 20 to 40 years and 60 to 80 years.

\section{DISCUSSION \\ Principal findings}

Our study compared hypertension status of persons resident in gas-flaring host communities with persons resident in communities in which oil exploration had never occurred. Findings from this study indicate that about one out of four adults interviewed in all six communities was hypertensive. About one-quarter and one-fifth of respondents were found to hypertensive in gas-flaring and non-gas-flaring communities respectively. This observed difference was not significant. However, after adjusting for confounding variables, age and residence in a gas-flaring host community were found to be the strongest predictors of hypertension status. Residents in a gas-flaring host community were 1.75 times more likely to be hypertensive than residents in non-gas-flaring communities. The interaction effects and model fit statistics identified age as the stronger predictor of hypertension. The age-adjusted probability of being hypertensive among those 20 to 40 and 60 to 80 years, was found to be higher among residents of a gas-flaring host community compared with residents of a non-gas-flaring host community.

\section{Implications}

A previous study done in other communities in the Niger Delta identified residence in a crude oil-polluted environment as a strong predictor of hypertension. It also identified age as the most important moderating variable in the relationship between oil pollution and hypertension. ${ }^{22}$ This identified relationship and interactions between hypertension status, age and residence in a gas-flaring host community may be explained by observed interactions between exposure to air pollution and metabolic changes underlying the development of hypertension, cardiovascular disease and diabetes observed by previous air pollution studies. ${ }^{12-15} 17182021$ The report of the United Nations Environment Programme (UNEP) in Ogoniland in South-South Nigeria ${ }^{24}$ and other research 
in the Ogoni axis in South-South Nigeria also support biological plausibility for this phenomenon. ${ }^{25-27}$

An alternative theory explaining the observation may be an increase in the adoption of negative lifestyle changes relating to improved socio-economic status resulting from the economic advantages that go along with residing in oilproducing communities. ${ }^{22}$ Study participants residing in gas-flaring host communities were significantly better educated, had a higher proportion of skilled jobs and were more overweight and obese than study participants residing in non-gas-flaring communities. This observation is in keeping with the theory of lifestyle-related risk factors strongly associated with non-communicable diseases. ${ }^{28-34}$

\section{Limitations and strengths}

This study did not evaluate the relationship between socio-economic status, modifiable risk factors, hypertension and residence in gas-flaring host communities. However, a previous study that did evaluate this relationship did not find any modifiable risk factor to have a significant association with oil pollution and hypertension. ${ }^{22}$ Our study also did not employ a longitudinal study design that is preferable for establishing temporal relationships. However, this study had a large sample size and employed rigorous sampling and statistical analysis. Finally, our study was unable, due to funding constraints, to conduct bio-monitoring of study participants to elicit the presence of specific pollutants. Further longitudinal research is needed in this regard to determine the longterm attributable effects of gas flaring on the health of persons living in the Niger Delta region of Nigeria

\section{CONCLUSION}

The implication of a significant relationship between gas-flaring and hypertension brings to the fore the need for regulatory activities that prevent and stop gas-flaring activities. There is also the need for greater efforts by government regulatory bodies such as the ministries of environment and health to scale up environmental and biological monitoring of pollutants.

Acknowledgements We acknowledge funding support from the Department for International Development (DFID) under the Climate Impacts Research Capacity and Leadership Enhancement (CIRCLE) Program. We also acknowledge the University of Port Harcourt (UNIPORT) and its teaching Hospital (UPTH) for approving a one-year study leave to enable $0 \mathrm{M}$ to undertake research activities.

Contributors $\mathrm{OM}$ wrote the protocol, conducted the research, did the data analysis and wrote the first draft of the manuscript. CT -W co-wrote the protocol, supported the data collection and revised the manuscript prior to submission.

Funding This research is supported by funding from the Department for International Development (DfID) under the Climate Impact Research Capacity and Leadership Enhancement (CIRCLE) programme.

Competing interests None declared.

Patient consent This was a population-based study. Client forms were signed by each study participant prior to administration of study tools.

Ethics approval Research Ethics Committee of the University of Port Harcourt.

Provenance and peer review Not commissioned; externally peer reviewed.
Data sharing statement Patient level data and full dataset isavailable from the corresponding author at omosivie.maduka@uniport.edu.ng. Thepresented data and data set are anonymised and risk of identification is low.

Open Access This is an Open Access article distributed in accordance with the Creative Commons Attribution Non Commercial (CC BY-NC 4.0) license, which permits others to distribute, remix, adapt, build upon this work non-commercially, and license their derivative works on different terms, provided the original work is properly cited and the use is non-commercial. See: http://creativecommons.org/ licenses/by-nc/4.0/

(C) Article author(s) (or their employer(s) unless otherwise stated in the text of the article) 2017. All rights reserved. No commercial use is permitted unless otherwise expressly granted.

\section{REFERENCES}

1. Oni SI, Oyewo MA. Gas flaring, transportation and sustainable energy development in the Niger-Delta, Nigeria. J Hum Ecol 2011;33:21-8.

2. Ikeke MO. Thomas Berry's idea of technological transformation its relevance to the management of oil technology in Nigeria' $s$ Niger delta. Thought Pract Assoc Kenya 2013;5:141-58.

3. Egwurugwu JN, Nwafor A, Ezekwe S. Effects of prolonged exposure to gas flares on the lipid profile of humans in the Niger delta region, Nigeria. Arch App/ Sci Res 2013;5:98-104.

4. Nigerian National Petroleum Corportaion. Oil Production in Nigeria. 2015 http://www.nnpcgroup.com/nnpcbusiness/upstreamventures/ oilproduction.aspx (accessed 7 May 2015).

5. American Association for the Advancement of Science. Geospatial Technologies and Human Rights Project: Eyes of Nigeria, 2011.

6. Friends of the Earth Limited. Gas flaring in Nigeria, 2004. Media Report 1649.

7. World Health Organization. Climate Change and Human Health: Risk and Responses. World Health Organization, 2003.

8. E. Ite A, J. Ibok U. Gas flaring and venting associated with petroleum exploration and production in the nigeria's niger delta. Amer $J$ Envi Prot 2013;1:70-7.

9. Vidal J. Gas flaring is wasting fuel and fueling climate change | climate central. Guardian Newspaper 2012 http://www. climatecentral.org/news/gas-flaring-is-wasting-fuel-and-fuelingclimate-change-15163 (accessed 7 May 2015).

10. U.S Energy Information Administration (EIA). Nigeria: Country Analysis Brief Overview. US EIA Independent statistics and analysis, 2015:1-20. http://www.eia.gov/countries/country-data.cfm?fips=ni (accessed 7 May 2015).

11. Ajugwo aO. Negative effects of gas flaring: the Nigerian experience. J Environ Pollut Hum Heal 2013;1:6-8.

12. Foraster M, Basagaña X, Aguilera I, et al. Association of long-term exposure to traffic-related air pollution with blood pressure and hypertension in an adult population-based cohort in Spain (the REGICOR study). Environ Health Perspect 2014;122:404-11.

13. Foraster M, Basagaña X, Aguilera I, et al. Association of long-term exposure to traffic-related air pollution with blood pressure and hypertension in an adult population-based cohort in Spain (the REGICOR study). Environ Health Perspect 2014;122:404.

14. Sughis M, Nawrot TS, Ihsan-ul-Haque S, et al. Blood pressure and particulate air pollution in schoolchildren of Lahore, Pakistan. BMC Public Health 2012;12:378.

15. Gobo A, Richard G, Ubong I. Health impact of gas flares on Igwuruta/Umuechem communities in Rivers State. J Appl Sci Environ Manage 2009;13:27-33.

16. Krewski $\mathrm{D}$, Burnett $\mathrm{R}$, Jerrett $\mathrm{M}$, et al. Mortality and long-term exposure to ambient air pollution: ongoing analyses based on the American Cancer Society cohort. J Toxicol Environ Health A 2005;68:1093-109.

17. Pope C, Burnett R, Thurston G, et al. Cardiovascular Mortality and Long-Term Exposure to Particulate Air Pollution. Circulation 2004;109:71-7.

18. Coogan PF, White LF, Jerrett M, et al. Air pollution and incidence of hypertension and diabetes mellitus in black women living in Los Angeles. Circulation 2012;125:767-72.

19. Dong GH, Qian ZM, Xaverius PK, et al. Association between longterm air pollution and increased blood pressure and hypertension in China. Hypertension 2013;61:578-84.

20. Chuang KJ, Yan YH, Chiu SY, et al. Long-term air pollution exposure and risk factors for cardiovascular diseases among the elderly in Taiwan. Occup Environ Med 2011;68:64-8. 
21. Chuang KJ, Yan YH, Cheng TJ. Effect of air pollution on blood pressure, blood lipids, and blood sugar: a population-based approach. J Occup Environ Med 2010;52:258-62.

22. Ezejimofor MC, Uthman OA, Maduka O, et al. The burden of hypertension in an oil- and gas-polluted environment: a comparative cross-sectional study. Am J Hypertens 2016;29:925-33.

23. Abramson JH. WINPEPI updated: computer programs for epidemiologists, and their teaching potential. EpidemiolPerspectlnnov 2011;8:1.

24. United Nations Environment Programme. Environmental assessment of Ogoniland. United Nations Environment programme, 2011.

25. Lindén O, Pålsson J. Oil contamination in Ogoniland, Niger delta. Ambio 2013;42:685-701.

26. Okparanma RN, Coulon F, Mouazen AM. Analysis of petroleumcontaminated soils by diffuse reflectance spectroscopy and sequential ultrasonic solvent extraction-gas chromatography. Environ Pollut 2014;184:298-305.

27. Kponee KZ, Chiger A, Kakulu II, et al. Petroleum contaminated water and health symptoms: a cross-sectional pilot study in a rural Nigerian community. Environ Health 2015;14:86.
28. Kinra S, Bowen LJ, Lyngdoh T, et al. Sociodemographic patterning of non-communicable disease risk factors in rural India: a cross sectional study. BMJ 2010;341:c4974.

29. Murray CJ, Lopez AD. Global mortality, disability, and the contribution of risk factors: Global Burden of Disease Study. Lancet 1997;349:1436-42

30. Beaglehole R, Yach D. Globalisation and the prevention and contro of non-communicable disease: the neglected chronic diseases of adults. Lancet 2003;362:903-8.

31. Lopez AD, Mathers CD, Ezzati M, et al. Global and regional burden of disease and risk factors, 2001: systematic analysis of population health data. Lancet 2006;367:1747-57.

32. Ezzati M, Lopez AD, Rodgers A, et al. Selected major risk factors and global and regional burden of disease. Lancet 2002;360:1347-60.

33. Murray CJL, Lopez AD. The global burden of disease: a comprehensive assessment of mortality and disability from deceases, injuries and risk factors in 1990 and projected to 2010. 1. Harvard University Press, 1996:1-35.

34. World Health Organization. Noncommunicable diseases: the slow motion disaster. WHO 2017 http://www.who.int/publications/10year-review/ncd/en/index4.html (accessed 7 May 2015). 